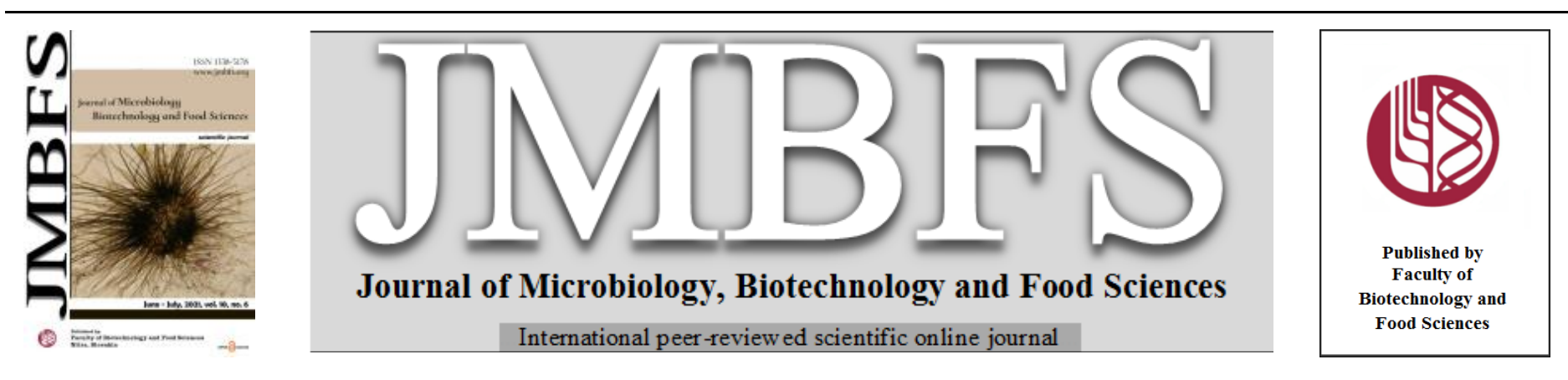

\title{
PURIFICATION AND PARTIAL CHARACTERISATION OF AN ANTIFUNGAL BACTERIOCIN FROM Bacillus sp. Sh10 ASSOCIATED WITH MARINE CARPET CLAM (Paphia textile)
}

\author{
Fatemeh Shayesteh"1, Asmat Ahmad ${ }^{2}$ \& Gires Usup ${ }^{3}$ \\ Address(es): \\ ${ }^{1}$ Department of Fisheries, Faculty of Marine Science and Technology, University of Hormozgan, Bandar Abbas, Iran. \\ ${ }^{2}$ School of Bioscience and Biotechnology, Faculty of Science and Technology, University Kebangsaan Malaysia, 43600 UKM Bangi, Selangor, Malaysia. \\ ${ }^{3}$ School of Environmental Science and Natural Resources, Faculty of Science and Technology, University Kebangsaan Malaysia, 43600 UKM Bangi, Selangor, \\ Malaysia.
}

*Corresponding author: Shayesteh_fatemeh@yahoo.com

https://doi.org/10.15414/jmbfs.2513

ARTICLE INFO

Received 4. 1. 2020

Revised 13. 1. 2021

Accepted 20. 1. 2021

Published 1. 6. 2021

Regular article

open 2 Access

\begin{abstract}
This study was conducted to purify and characterize an anti- C. albicans bacteriocin produced by Bacillus sp. Sh10 isolated from marine carpet clam, Paphia textile. Extracellularly produced bacteriocin was purified by $80 \%$ ammonium sulfate precipitation and size exclusive gel chromatography using superdex-200 column chromatographyThe purification steps resulted in 3.68 -fold increase in specific activity and recovery of $20.66 \%$ of total activity. The purity rate and molecular mass of $11 \mathrm{KDa}$ of this compound were determined using sodium dodecyl sulfate-polyacrylamide gel electrophoresis (SDS-PAGE). Profile analysis of this bacteriocin by electrospray mass spectrometry (LC/MS/MS) showed $43 \%$ protein sequence coverage with a putative uncharacterized protein from Bacillus cereus strain B4264.
\end{abstract}

Keywords: Marine bacteria, antifungal bacteriocin, Candida albicans, Bacillus sp., purification

\section{INTRODUCTION}

Bacteriocins are generally defined as antimicrobial peptides produced by bacteria that inhibit or kill microorganisms closely-related or non-related to produced bacteria (Leroy \& De Vuyst, 2004; Cotter et al., 2005).

The members of Bacillus genus are known to produce a variety of bacteriocins consisting of a hydrophobic fatty acid linked to a hydrophilic peptide chain (Roongsawang et al., 2011). This complex structural diversity warrants the broad spectra of inhibition of some Bacillus strains, which includes not only Gram-positive and Gram-negative bacteria, but fungi and amoeba as well (Benitez et al., 2011; Shelburne et al. 2007; Cladera-Olivera et al., 2004).

The pathogenicity of $C$. albicans makes it particularly troublesome for patients with immunosuppression conditions. Indeed increasing numbers of diabetics, HIV type-C patients, post-surgical patients, premature infants, and trauma patients are progressively vulnerable to $C$. albicans infections. These infections can be localized to the gastrointestinal, oral, or vaginal tracts, or be disseminated across multiple sites and organs, which can be fatal. The mortality rate in patients infected with C. albicans, exceeds $40 \%$ (Gudlaugsson et al., 2003).

During the past five decades, systemic antifungal treatments have been devised (Ostrosky-Zeichner et al., 2010); yet, new antifungals are urgently needed to offset the rising incidence of invasive fungal infections arising from C. albicans and other pathogens becoming drug-resistant (Shahin et al., 2015; Amel et al., 2015; Adebayo \& Aderiye, 2011). To be effective, these new treatments will need to go beyond conventional drug targets, to focus instead upon new targets such as novel metabolic pathways or virulence factors.

This report describes the partial purification and identification of anti-C. albicans bacteriocin, which is produced by Bacillus sp. sh10 isolated from Paphia textile.

\section{MATERIAL AND METHODS}

Isolation, detection and partial purification of bacteriocin

In the present study, a bacteriocin produced from Bacillus sp. sh10 was used. This microorganism was isolated previously from carpet clam (P. textile) (Shayesteh et al., 2014, 2015). Inorganic salt medium (Pridham \& Gottlieb, 1948) containing $2 \%$ tryptone and $1 \%$ glucose as nitrogen and carbon source, respectively followed by $2 \%$ sodium chloride was obtained as an optimized medium for bacteriocin production by isolate sh10 (Shayesteh et al., 2014). In addition, the optimized culture media was adjusted to $\mathrm{pH} 8.0$ and bacteria culture was incubated at $30{ }^{\circ} \mathrm{C}$ under the aerobic condition for $30 \mathrm{~h}$. Afterwards, the supernatant was achieved by centrifuging bacteria culture at $3000 \times \mathrm{g}$ for $30 \mathrm{~min}$ at $4{ }^{\circ} \mathrm{C}$. The supernatant which was obtained after centrifugation was then filtered by $0.22 \mu \mathrm{m}$ membrane filter followed by ammonium sulfate precipitation at a different percentage of saturation $(40 \%-60 \%$ and $80 \%)$ at $4{ }^{\circ} \mathrm{C}$. After moderate agitation, the precipitated protein obtained by centrifugation $(3000 \mathrm{~g}$, $30 \mathrm{~min}, 4^{\circ} \mathrm{C}$ ), was dissolved in $0.1 \mathrm{M}$ phosphate buffer $(\mathrm{pH}$ 7.0) followed by dialysing via dialysis membrane ( $2 \mathrm{KDa}$ cut-off, sigma) against the same buffer at $4{ }^{\circ} \mathrm{C}$ for $24 \mathrm{~h}$ (Rajaram et al., 2010) and applied as ammonium sulfate fraction.

The antimicrobial activity of bacteriocin against $C$. albicans ATCC 10231 was determined using the spot-on-lawn method (Seuk-Hyun \& Cheol, 2000). In brief, in each step of purification, $10 \mu \mathrm{L}$ of bacteriocin was spotted onto the surface of tryptone soy agar overlaid by $1.5 \times 10^{8} \mathrm{CFU} / \mathrm{mL}$ cells of the $C$. albicans followed by incubation at $30{ }^{\circ} \mathrm{C}$ for $48 \mathrm{~h}$. A bacteriocin titer was determined as the reciprocal of the highest twofold dilution indicating the complete inhibition of the indicator lawn and was presented in activity units (AU) per $\mathrm{ml}$ of culture media. The titer of the bacteriocin solution, in $\mathrm{AU} / \mathrm{mL}$, was calculated as (1000/d) D, where D is the dilution factor and $d$ is the dose (Hoover \& Harlander, 1993).

\section{Gel filtration chromatography}

The dialyzed protein was placed in a Superdex-200 column (AKTA purifier UPC-900) at room temperature. The protein was eluted with phosphate buffer $(0.1 \mathrm{M}, \mathrm{pH} 7.0)$ at a flow rate of $0.5 \mathrm{~mL} / \mathrm{min}$ and screened at $280 \mathrm{~nm}$. Fractions $(1 \mathrm{~mL})$ were collected and evaluated in terms of antimicrobial activity by spotting aliquots $(10 \mu \mathrm{L})$ on a lawn of $C$. albicans, as described previously. The molecular weight of bacteriocin was calculated through gel filtration with aprotinin (6.5 $\mathrm{kDa})$, ribonuclease A (13.7 kDa), carbonic anhydrase (29 kDa), ovalbumin (44 $\mathrm{kDa})$, conalbumin $(75 \mathrm{kDa})$, aldolase $(158 \mathrm{kDa})$, and ferritin $(440 \mathrm{kDa})$ as references. 
Sodium dodecyl sulfate-polyacrylamide gel electrophoresis (SDS-PAGE) analysis

The active fractions acquired from gel filtration chromatography were analyzed by $15 \%$ SDS-PAGE and Tris-Glycine buffer system (Laemmli, 1970) to verify the purity. A pre-stained broad-range molecular mass marker (11- $245 \mathrm{KDa}$ GeneDirex) was utilized to assess the bacteriocin molecular weight. In order to enter the samples into the separating gel, the electrophoresis was performed at 50 $\mathrm{V}$ and was followed by a constant power of $100 \mathrm{~V}$ until samples achieved the endpoint of the separating gel. Fractions containing a single band were pooled and designed as gel filtrate fractions.

\section{Direct detection of the bacteriocin activity on SDS-PAGE}

The protein band activity in SDS-PAGE was assayed as described by Cherif $\boldsymbol{e}$ al. (2001). After the samples were run, the gel was vertically cut into two halves. The first half was stained by Coomassie blue R-250 to observe the protein bands the other half was rinsed with deionized water for $2 \mathrm{~h}$ with intermediate steps of changing the water every $20 \mathrm{~min}$. Afterward, the gel was placed in a sterile Petri dish and subjected to UV for 20 min for sterilization. The gel was then overlaid with Mueller Hinton soft agar seeded with $1.5 \times 10^{8} \mathrm{CFU} / \mathrm{mL}$ cells of $C$. albicans followed by incubation at $30{ }^{\circ} \mathrm{C}$. After $24-48 \mathrm{~h}$ of incubation, the gel was examined to determine the growth inhibition zone caused by bacteriocin.

\section{Determination of protein concentration}

The protein concentrations of the samples obtained from culture supernatant, ammonium sulfate precipitation, and gel filtration were determined in accordance with Bradford assay (Bradford, 1976). Bradford solution was added to $100 \mu \mathrm{L}$ aliquots containing different bovine serum albumin (BSA) concentrations and bacteriocin samples. These samples were incubated at room temperature for 10 min. The absorbance at $595 \mathrm{~nm}$ was also determined using a spectrophotometer BSA standards were used to create a standard curve, and the protein concentration of the samples was calculated on the basis of this standard curve.

\section{Identification of bacteriocin using mass spectrometry (LCMS/MS)}

Active bands on SDS-PAGE corresponding to a molecular weight of approximately $11 \mathrm{kDa}$ was excised from the gel. The process involved in-gel destaining, reduction with dithiothreitol, alkylation of the thiols with iodoacetamide, and in-gel tryptic digestion and extraction of the resulting peptides (Proteomics International Facility, Australia). The extracted peptides were analyzed through electrospray ionization mass spectrometry by Agilent 1260 Infinity HPLC System coupled with an Agilent 6540 mass spectrometer Tryptic peptides were loaded onto a $5 \mu \mathrm{m} 300$ SB C18 column (Agilent) and separated with a linear gradient of water/acetonitrile/0.1\% formic acid (v/v). The spectra were analyzed to recognize the target proteins by Mascot sequence matching software [Matrix Science] with Ludwig NR database.

\section{RESULTS}

Extraction, purification, and molecular weight determination of bacteriocin produced by Bacillus sp. Sh10

The highest bacteriocin activity was found at $80 \%$ of ammonium sulfate precipitation, which resulted in a 3.68-fold increase in the specific activity. This purification step resulted in $494.42 \mathrm{AU} / \mathrm{mg}$ and $20.66 \%$ of specific activity and total activity recovery, respectively (Table 1). The separation profile of gel filtration chromatography (superdex-200) achieved from crude ammonium sulfate precipitate, resulted in two major peaks (Figure 1). Among 36 fractions collected, antimicrobial activity was trailed in fractions 23-27 which were located in the second peak (Figure 1). When active fractions obtained from gel chromatography were compared to the standard curve, the molecular weight of eluted peptides in these fractions corresponded to $~ 13-6 \mathrm{kDa}$. The present purification step resulted in $546.22 \mathrm{AU} / \mathrm{mg}$ and $6.5 \%$ of specific activity and total activity recovery, respectively (Table 1 ). The ammonium sulfate precipitate and active fractions of bacteriocin collected from size exclusion gel chromatography were examined by SDS-PAGE (Figure 2). The accurate molecular weight of antimicrobial peptide was measured by SDS-PAGE. In the case of ammonium sulfate precipitation, seven major and other bands were observed with different molecular weights compared with a broad range molecular marker (Figure 2A) The bacteriocin activity against $C$. albicans ATCC 10231 corresponded to a lowmolecular-weight band with an estimated molecular mass of $11 \mathrm{kDa}$ (Figure 2B). Based on the active fractions from gel chromatography, fractions 23 and 24 contained more than one band, indicating the impurity of these fractions. However, fractions 25, 26, and 27 showed single sharp bands as indicated by SDS-PAGE (Figure 2). The bacteriocin activity of fractions 23-27 on SDSPAGE against $C$. albicans ATCC 10231 (Figure 2B) was exhibited as a clear zone of inhibition on the corresponding band ( $11 \mathrm{kDa})$. Therefore, fractions 25 , 26 , and 27 with the single band were pooled and designed as gel filtrate fraction of bacteriocin.

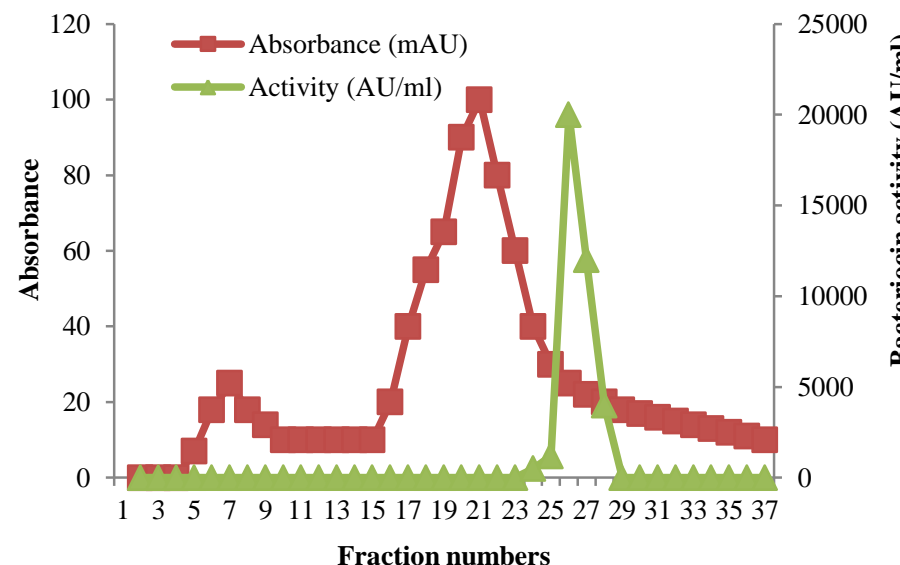

Figure 1 Elution profile of bacteriocin from isolate Sh10 on superdex-200 column chromatography

Table 1 Purification steps of bacteriocin produced by isolate Sh10

\begin{tabular}{|c|c|c|c|c|c|c|c|c|}
\hline $\begin{array}{l}\text { Purification } \\
\text { steps }\end{array}$ & $\begin{array}{c}\text { Volume } \\
\text { (mL) }\end{array}$ & $\begin{array}{c}\text { Activity } \\
\text { unit }^{1} \\
\text { (AU/mL) }\end{array}$ & $\begin{array}{l}\text { Protein }^{2} \\
(\mathrm{mg} / \mathrm{mL})\end{array}$ & $\begin{array}{c}\text { Total } \\
\text { protein }^{3} \\
(\mathbf{m g})\end{array}$ & $\begin{array}{c}\text { Total } \\
\text { activity }^{4} \\
(\mathrm{AU})\end{array}$ & $\begin{array}{l}\text { Specific } \\
\text { activity } \\
\text { (AU/mg) } \\
\end{array}$ & Purification fold ${ }^{6}$ & $\operatorname{Recovery}^{7}(\%)$ \\
\hline $\begin{array}{l}\text { Culture } \\
\text { supernatant }\end{array}$ & 1000 & 1200 & 8.93 & 8930 & 1200000 & 134.38 & 1 & 100 \\
\hline $\begin{array}{l}\text { Ammonium } \\
\text { sulfate } \\
\text { precipitation } \\
(80 \%)\end{array}$ & 80 & 3100 & 6.27 & 501.6 & 248000 & 494.42 & 3.68 & 20.66 \\
\hline $\begin{array}{c}\text { Gel } \\
\text { filtration }\end{array}$ & 30 & 2600 & 4.76 & 142.8 & 78000 & 546.22 & 4.06 & 6.5 \\
\hline
\end{tabular}

Activity unit $(\mathrm{AU} / \mathrm{mL})=$ Reciprocal of the highest dilution $\times 1000 /$ volume of bacteriocins added; ${ }^{2}$ Protein concentration measured by Bradford's method; ${ }^{3}$ Total protein $=$ protein concentration $\times$ total volume; ${ }^{4}$ Total activity $=$ Activity $(\mathrm{AU} / \mathrm{mL}) \times$ Total volume; ${ }^{5}$ Specific activity $($ AU $/ \mathrm{mg})=$ Total activity of the subsequent purification step/Total protein of the same step; ${ }^{6}$ Fold purification $=$ Specific activity of subsequent step/ Specific activity of crude preparation; ${ }^{7}$ Recovery $(\%)=$ Total activity of subsequent step $\times 100 /$ Total activity of crude preparation. 

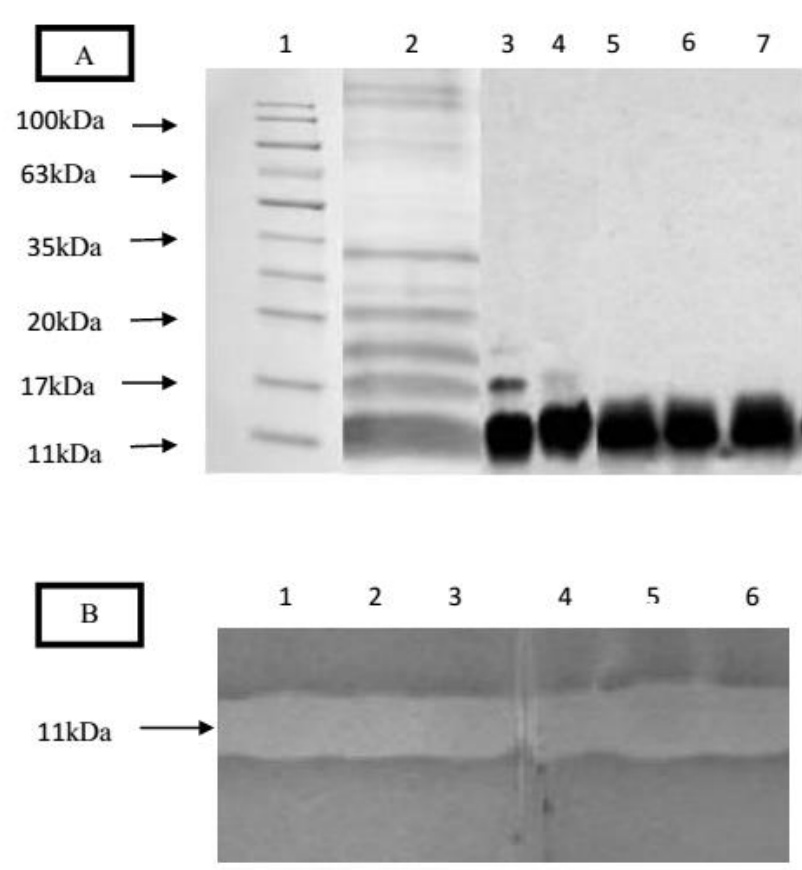

Figure 2 SDS-PAGE profile of bacteriocin produced by Bacillus sp. Sh10. A Gel stained with coomassie blue R250. Lane 1, broad range molecular weight marker (Gen Direx); lane 2, bacteriocin precipitated with $80 \%$ ammonium sulfate; lanes 3,4,5,6,7, gel exclusive chromatography fractions 23-27 respectively; B, SDS-Polyacrylamide gel overlaid with C. albicans ATCC 10231 showing the inhibitory effect (arrow) of bacteriocin. Lane 1, bacteriocin precipitated with $80 \%$ ammonium sulfate; lanes 2,3,4,5,6, gel exclusive chromatography fractions $23-27$, respectively.

\section{Identification of bacteriocin by LC-MS/MS}

The gel-filtration purified band that showed anti-Candida activity in SDS-PAGE gel overlay assay was exposed to LC-MS/MS analysis. The result from Mascot Sequence Matching Software [Matrix Science] with Ludwig NR database showed 43\% identity of bacteriocin produced by isolate Sh10 with uncharacterized protein Tax_Id=405532 from B. cereus [strain B4264]. Out of 105 amino acids of the uncharacterized protein Tax $I d=405532,46$ amino acids were detected by LC-MS/MS, and the subsequent data analysis showed a $43 \%$ sequence similarity with the score of 175 with the uncharacterized protein Tax_Id=405532 from B. cereus [strain B4264] (Figures 3 and 4). Based on the LC-MS/MS, the peaks corresponding to NFNTIDVTMNLNELYVLSGR (score: 66, expected value: 0.0085 ), SIDILSGDK (score: 18 , expected value: $1.3 \mathrm{e}+03$ ), SIDILSGDK (score: 33, expected value: 41), SIDILSGDKEAIQLNK (score: 70, expected value: 0.0043), and EAIQLNKYTISFNKPGK (score: 5, expected value: $1.3 \mathrm{e}+04$ ) were detected in the mass spectra (Figure $3 \mathrm{~A}-\mathrm{E}$ ).

In addition, the detected amino acids by LC-MS/MS did not show identity or homology to the antimicrobial peptides available at the antimicrobial peptide database. The overall view of the matched protein is summarized below.

Protein view:

MASCOT search result: Protein tr|B7HDM0|BCB4264_A3844 B7HDM0_BACC4 Uncharacterized protein $\mathrm{n}=3$ Tax_Id=405532 [Bacillus cereus (strain B4264)]

Database: Ludwig NR

Score: 175

Nominal mass $\left(\mathrm{M}_{\mathrm{r}}\right): 11558 \mathrm{Da}$

Calculated PI: 7.77

Protein sequence coverage: $43 \%$

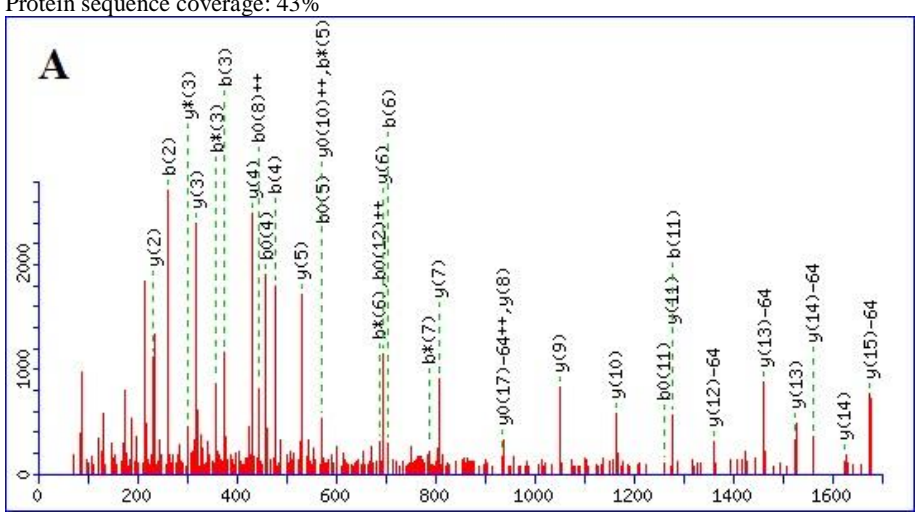

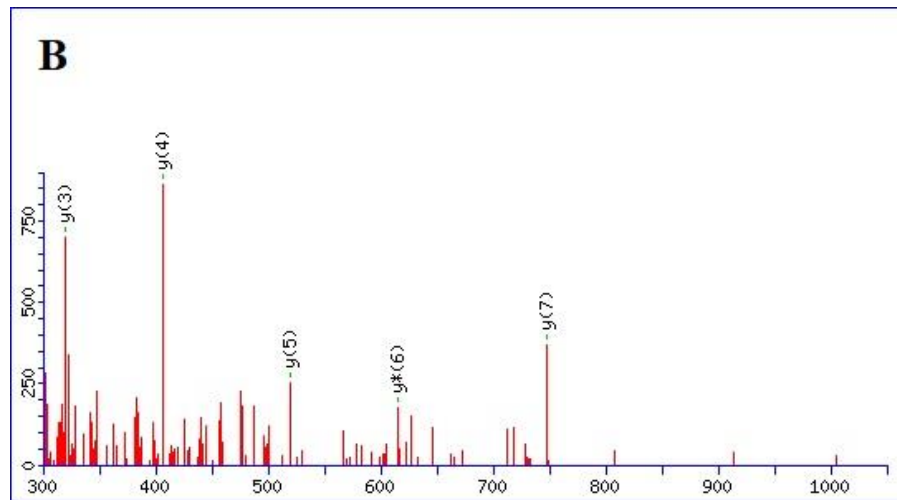

C

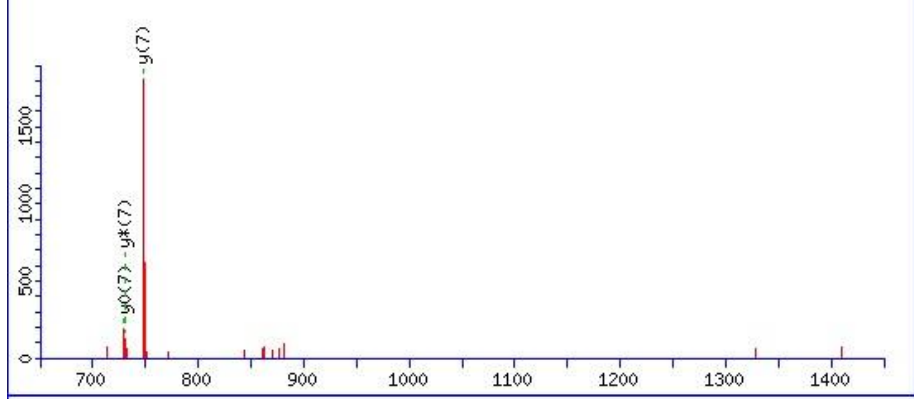

D

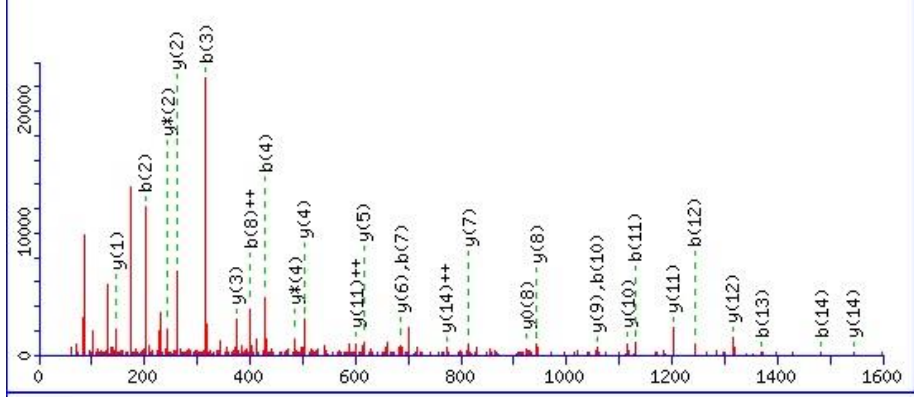

$\mathbf{E}$

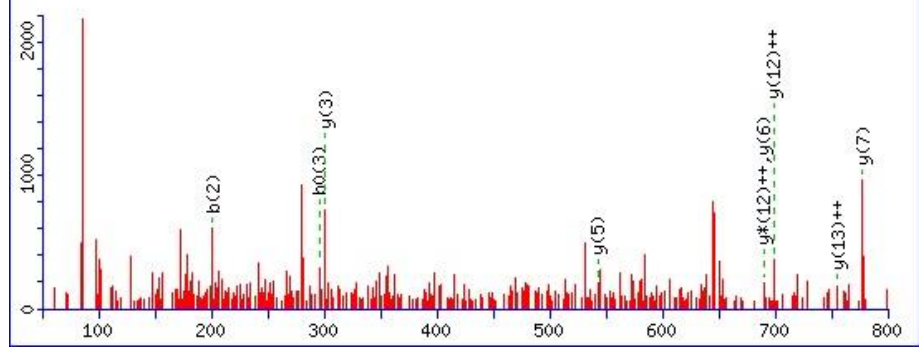

Figure 3 MALDI-TOF spectra of $\quad$ peptide; (A) peptide NFNTIDVTMNLNELYVLSGR, (B) peptide SIDILSGDK, (C) peptide SIDILSGDK, (D) peptide SIDILSGDKEAIQLNK and (E) peptide EAIQLNKYTISFNKPGK.

\section{MKQIKKFAGV ALAGTIGLSG LLFLEPSVSV AEAQQVKVKN FNTIDVTMNL 51 NELYVLSGRS IDILSGDKEA IQLNKYTISF NKPGKYVIKV NGCIYDDVYT 101 FIVNE}

Figure 4 Amino acid sequence of uncharacterized protein $n=3$ Tax $I d=405532$ [Bacillus cereus (strain B4264)]. The underline sequences reveal those that matched with that of experimental sample from SDS-PAGE active band. The sequence coverage was $43 \%$ with a score of 175 [Protein scores are derived from ions scores as a non-probabilistic basis for ranking protein hits. Ions score is $10 * \log (\mathrm{P})$, where $\mathrm{P}$ is the probability that the observed match is a random event. Individual ions scores $>59$ indicate identity or extensive homology $(\mathrm{p}<0.05)]$. 


\section{DISCUSSION}

Protein fractionation is usually performed through ammonium sulfate precipitation as it facilitates concentration of dilute protein solutions (Whitford et al., 2001). This approach also prevents protein denaturation and makes it possible to restore activity after re-dissociation. Proteolysis and contamination by bacteria of proteins are hindered by ammonium sulfate as well (Harris \& Angal, 1989). Enhanced purification is generally achieved by taking an ammonium sulfate cut. Bioactivity assays of the ammonium sulfate precipitate fraction and active fractions from gel filtration chromatography on SDS-PAGE suggested that inhibitory activity was due to a low molecular weight protein $(\sim 11 \mathrm{KDa})$ Bacteriocin activity can be most easily, accurately, and rapidly identified through the common method of SDS-PAGE (Crupper \& Iandolo, 1996).

In our previous study, we demonstrated that among different enzymes tested for bacteriocin sensitivity, lysozyme, $\alpha$-amylase, lipase, and proteinase $\mathrm{K}$ did not alter bacteriocin activity, but complete inactivation was observed after treatment with trypsin. The inhibitory compound was heat resistant and the antimicrobial activity of the present bacteriocin did not alter after autoclaving (Shayesteh et al., 2015). Although the present bacteriocin possessed the same range of molecular weight as other bacteriocins from B. cereus group members but differed in physico-chemical characteristics. For example, cerein GN105 (9 KDa) produced by B. cereus GN105 (Naclerio et al., 1993) differed from the present bacteriocin in terms of heat stability (stable until $\left.75{ }^{\circ} \mathrm{C}\right)$. Tochicin $(10.5 \mathrm{KDa}$ ) and thuricin (11.6 KDa) produced by $B$. thuringiensis spp. tochigiensis HD868 (Paik et al. 1997) and B. thuringiensis BMG1.7 (Cherif et al., 2001), respectively, both differed from the present bacteriocin in terms of proteinase $K$ susceptibility and heat stability (complete inactivation by heating at $121{ }^{\circ} \mathrm{C}$ for 20 $\mathrm{min}$ ). However, SDS-PAGE identifies as BLIS of approximately $10 \mathrm{kDa}$ compounds synthesised by Mexican B. thuringiensis, including Morricin 269 from B. thuringiensis ssp. morrisoni (LBIT 269), kurstacin 287 from $B$. thuringiensis ssp. kurstaki (LBIT 287), kenyacin 404 from B. thuringiensis ssp. kenyae (LBIT 404), entomocin 420 from B. thuringiensis ssp. entomocidus (LBIT 420), and tolworthcin 524 from B. thuringiensis ssp. tolworthi (LBIT 524) (Barboza-Corona et al., 2007; De la Fuente-Salcido et al., 2008). Depending on heat stability, two uniform groups of such BLIS was distinguished via partial purification. The first group comprises morricin 269 and kurstacin 287, which show tolerance to heat and retain their stability up to $80^{\circ} \mathrm{C}$. Meanwhile, the second group consists of the rest of the BLIS, which exhibit resistance to heat and retain their stability up to $121^{\circ} \mathrm{C}$. The characteristic which differentiates BLIS from second group from the present bacteriocin is their complete loss of activity after exposure to proteinase $\mathrm{K}$. The heat resistance, protease sensitivity, and low molecular weight of the present bacteriocin indicate that it belongs to group II bacteriocin (Klaenhammer, 1993).

The gel-purified band corresponding to approximately $11 \mathrm{KDa}$ was analyzed by LC-MS/MS. Mascot software showed 43\% similarity to an uncharacterized protein from B. cereus B4264 (46 out of 105 amino acids showed homology). We compared the present bacteriocin's amino acid sequence with those of other bacteriocins in the NCBI and Antimicrobial Peptide Database. Sequence comparison showed no matches to the partial sequence obtained from LCMS/MS and to the uncharacterized protein from B. cereus B4264. The nonhomology between the present bacteriocin and previously isolated bacteriocins confirms that the bacteriocin produced by isolate Sh10 is a novel bacteriocin.

The present bacteriocin has a high amount of cationic amino acids, a net charge of +1 , and a high percentage of hydrophobicity (42\%). Given these characteristics, bacteriocin produced by Bacillus sp. Sh10 may exert its action by interacting with cell-wall-associated or membrane-associated binding sites in sensitive $C$. albicans cells. These findings indicated that the net positive charge of present bacteriocin would interact with the negative charges of phosphate groups in the cell walls of sensitive cells by a strong electrostatic interaction, resulting in pore formation, which allowed for the efflux of intracellular materials, ultimately leading to cell death.

According to Akkam (2016), antifungal peptides are cationic and possess positive net charges of $+1-+5$. For example, the antifungal peptide Heliomicin isolated from the worm Heliothis virescens has a net charge of +1 . Heliomicin exhibits an inhibitory effect on two pathogenic fungi, C. albicans and Candida neoformans (Lamberty et al. 2001). Maximin 1 has a net charge of +3 and inhibits $C$. albicans growth (Lai et al. 2002). Apart from peptide net charge, peptide hydrophobicity is also required for peptide membrane interaction and membrane permeabilization. peptide hydrophobicity is also control the peptide portioning into the phospholipid layer. Previous study proposed that the hydrophobic value of vast majority of antifungal proteins are in the range of 30\% and $60 \%$ (Akkam, 2016). The calculated hydrophobicity of this bacteriocin was $42 \%$. Overall, it is assumed that these two properties of bacteriocin produced by Bacillus sp. Sh10 had a great impact on its function which is pore formation.

\section{CONCLUSION}

In conclusion, the present antifungal bacteriocin is a novel bacteriocin Furthermore, elucidation of the structure and the genetic determination of this bacteriocin can provide insights into its further classification and functional relationship to its mode of action.

Acknowledgements: This work was supported by University Kebangsaan Malaysia (Faculty of Science and Technology).

\section{REFERENCES}

Adebayo, C.O., \& Aderiye, B.I. (2011). Suspected mode of antimycotic action of brevicin SG1 against Candida albicans and Penicillium citrinum. Food Control, 22 (12), 1814-1820. http://doi: 10.1016/j.foodcont.2011.04.013

Akkam, Y. (2016). A Review of Antifungal Peptides: Basis to New Era of Antifungal Drugs. Jordan Journal of Pharmaceutical Sciences, 9 (1), 51-75.

Amel, M.S., Sohair, R.F., \& Wessam, A.M. (2015). Therapeutic efficacy of chitosan against invasive candidiasis in mice. The Journal of Basic \& Applied Zoology, 72, 163-172. http://doi: 10.1016/ j.jobaz.2014.12.001

Barboza-Corona, J. E., Vazquez-Acosta, H., Bideshi, D. K., \& SalcedoHernandez, R. (2007). Bacteriocin-like inhibitor substances produced by Mexican strains of Bacillus thuringiensis. Archives Microbiology, 187 (2), 117 126. http://doi: 10.1007/s00203-006-0178-5

Benitez, L.B., Caumo, K., Brandelli, A., \& Rott, M.B. (2011). Bacteriocin-like substance from Bacillus amyloliquefaciens shows remarkable inhibition of Acanthamoeba polyphaga. Parasitology Research, 108 (3), 687-691. http:// doi: 10.1007/s00436-010-2114-5

Bradford, M.M. (1976). A rapid and sensitive method for the quantitation of microgram quantities of protein utilizing the principle of protein-dye binding. Analytical Biochemistry, 72 (1-2), 248-54. http://doi: 10.1006/abio.1976.9999

Cherif, A., Chehimi, S., Limem, F., Hansen, B. M., Hendriksen, N. B., Daffonchio, D., \& Boudabous, A. (2003). Detection and characterization of the novel bacteriocin entomocin 9, and safety evaluation of its producer, Bacillus thuringiensis subsp. Entomocidus HD9. Journal of Applied Microbiology, 95 (5), 990-1000. http://doi:10.1046/j.1365-2672.2003.02089.x

Cherif, A., Ouzari, H., Daffonchio, D., Cherif, H., Ben Slama, K., Hassen, A., ... \& Boudabous, A. (2001). Thuricin 7: a novel bacteriocin produced by Bacillus thuringiensis BMG1.7, a new strain isolated from soil. Journal of Applied Microbiology, 32 (4), 243-247. http://doi: 10.1046/j.1472-765x.2001.00898.x Cladera-Olivera, F., Caron, G. R., \& Brandelli, A. (2004). Bacteriocin-like substance production by Bacillus licheniformis strain P40. Letters in Applied Microbiology, 38 (4), 251-256. http://doi: 10.1111/j.1472-765x.2004.01478.x

Cotter, P. D., Hill, C., \& Ross, R. P. (2005). Bacteriocins: developing innate immunity for food. Nature Reviews Microbiology, 3 (10), 777-788. http://doi: 10.1038/nrmicro1273

Crupper, S.S., \& Iandolo, J.J. (1996). Purification and partial characterization of a novel antibacterial agent (Bac1829) produced by Staphylococcus aureus KSI1829. Applied Environmental Microbiology, 62 (9), 3171-3175.

De la Fuente-Salcido, N., Alanís-Guzmán, M.G., Bideshi, D.K., SalcedoHernández, R., Bautista-Justo, M., \& Barboza-Corona, J.E. (2008). Enhanced synthesis and antimicrobial activities of bacteriocins produced by Mexican strains of Bacillus thuringiensis. Archives Microbiology, 190 (6), 633-640. http://doi:10.1007/s00203-008-0414-2

Gavanji, S., Zaker, S.R., Nejad, Z.G., Bakhtari, A., Bidabadi, E.S., \& Larki, B. (2015). Comparative efficacy of herbal essences with amphotricin B and ketoconazole on Candida albicans in the in vitro condition. Integrative Medicin Research, 4 (2), 112-118. htpp://doi.org/10.1016/j.imr.2015.01.003

Gudlaugsson, O., Gillespie, S., LEE, K., Vande Berg, J., HU, J., MESSER, S., ... \& Diekema, D. (2003). Attributable mortality of nosocomial candidemia, revisited. Clinical Infectious Diseases, 37 (9), 1172-1177. http://doi $10.1086 / 378745$

Harris, E.L.V., \& Angal, S. (1989). Protein purification Methods: A practical Approach. IRL Press, Oxford, pp. 210-290.

Hoover, D.G., \& Harlander, S.K. (1993). Screening Methods for Detecting Bacteriocin Activity. In: Hoover, D.G., \& Steenscr. L.R., (Eds.), Bacteriocins of Lactic Acid Bacteria. Academic Press, San Diego, pp: 23-39.

Hyronimus, B., Le Merrec, C., \& Urdaci, M.C. (1998). Coagulin: A bacteriocinlike inhibitory substance produced by Bacillus coagulans I4. Journal of Applied Microbiology, 85 (1), 42-50. http://doi: 10.1046/j.1365-2672.1998.00466.x

Klaenhammer, T. R. (1993). Genetics of bacteriocins produced by lactic acid bacteria. Federation of European Microbiological Societies Microbiol Review, 12 (1-3), 39-85. http://doi:10.1111/j.1574-6976.1993.tb00012.x

Laemmli, U.K. (1970). Cleavage of structural proteins during the assembly of the head of bacteriophage T4. Nature, 227 (5259): 680-685. http://doi: $10.1038 / 227680 \mathrm{a} 0$

Lai, R., Zheng, YT., Shen, J.H., Liu, GJ., Liu, H., Lee, W.H., ... \& Zhang, Y. 2002. Antimicrobial peptides from skin secretions of Chinese red belly toad Bombina maxima. Peptides, 23 (3), 427-435. http://doi: 10.1016/s01969781(01)00641-6

Lamberty, M., Caille, A., Landon, C., TassinMoindrot, S., Hetru, C., Bulet, P., \& Vovelle, F. (2001). Solution structures of the antifungal heliomicin and a selected variant with both antibacterial and antifungal activities. Biochemistry, 40 (40), 11995-12003. http://doi: 10.1021/bi0103563 
Leroy, F., De Vuyst, L. (2004). Lactic acid bacteria as functional starter cultures for the food fermentation industry. Trends in Food Science and Technology, 15 (4), 67-78. http://doi: 10.1016/i.tifs.2003.09.004

Naclerio, G., Ricca, E., Sacco, M., \& de Felice, M. (1993). Antimicrobial activity of a newly identified bacteriocin of Bacillus cereus. Applied and Environmental Microbiology, 59 (12), 4313-4316.

Ostrosky-Zeichner, L.L., Casadevall, A., Galgiani, J.N., Odds, F.C., \& Rex, J.H (2010). An insight into the antifungal pipeline: selected new molecules and beyond. Nature Reviews Drug Discovery, 9 (9), 719-727. http://doi $10.1038 / \mathrm{nrd} 3074$

Paik, H. D., Bae, S. S., \& Pan, J. G. (1997). Identification and partial characterization of tochicin, a bacteriocin produced by Bacillus thuringiensis subsp. tochigiensis. Journal of Industrial Microbiology \& Biotechnology, 19 (4), 294-298. http://doi: 10.1038/sj.jim.2900462

Pridham, T.G., \& Gottlieb, D. (1948). The utilization of carbon compounds by some Actinomycetales as an aid for species determination. Journal of Bacteriology, 56 (1), 107-114.

Roongsawang, N., Washion, K., \& Morikawa, M. (2011). Diversity of nonribosomal peptide synthetases involved in the biosynthesis of lipopeptide biosurfactants. International Journal of Molecular Sciences, 12 (1), 141-172. http:// doi: 10.3390/ijms12010141

Seuk-Hyun, K., \& Cheol, A. (2000). Bacteriocin production by Lactococcus lactis KCA 2386 isolated from white kimchi. Food Science and Biotechnology, 9 , 263-269.

Shayesteh, F., Ahmad, A., \& Usup, G. (2014). Bacteriocin production by a marine strain of Bacillus sp. Sh10: Isolation, screening and optimization of culture condition. Biotechnology, $13 \quad$ (6), 273-281. http://doi:10.3923/biotech.2014.273.281

Shayesteh, F., Ahmad, A., \& Usup, G. (2015). Partial Characterization of an Anti-Candida albicans Bacteriocin Produced by a Marine Strain of Bacillus sp. Sh10. Advance Journal of Food Science and Technology, 9 (9), 664-671. http: //doi: 10.19026/ajfst.9.1757

Shelburne, C.E., An, F.Y., Dholpe, V., Ramamoorthy, A., Lopatin, D.E., \& Lantz, M.S. (2007). The spectrum of antimicrobial activity of the bacteriocin subtilosin A. Journal of Antimicrobial Chemotherapy, 59 (2), 297-300. http://doi: 10.1093/jac/dk1495

Whitford, W.F., McPherson, M.A., Foster, R.J., \& Teather, R.M. (2001)

Identification of bacteriocin-like inhibitors from rumen Streptococcus spp. and isolation and characterization of Bovicin 255. Applied Environmental Microbiology, 67(2), 569-574. http://doi: 10.1128/AEM.67.2.569-574.2001 